\title{
MONOCULTIVOS DE DENDEZEIROS, CAPITAL TRANSNACIONAL E CONCENTRAÇÃO DE TERRAS NA AMAZÔNIA PARAENSE
}

\section{LA MONOCULTURE D'HUILE DE PALME, LE CAPITAL TRANSNATIONAL ET LA CONCENTRATION DES TERRES SUR L'AMAZONIE AU PARÁ}

\begin{abstract}
Elielson Pereira da Silva
Administrador, Mestrando em Gestão de Recursos Naturais e Desenvolvimento Local na Amazônia, Universidade Federal do Pará (UFPA) epsilva@ufpa.br

Sônia Barbosa Magalhães Antropóloga, Professora Permanente do Programa de Pós-Graduação em Agriculturas Amazônicas e pesquisadora, Universidade Federal do Pará smag@ufpa.br

André Luís Assunção de Farias Sociólogo, Professor Permanente do Programa de Pós-Graduação em Gestão de Recursos Naturais e Desenvolvimento Local na Amazônia, Universidade Federal do Pará andrefarias@ufpa.br
\end{abstract}

\section{Resumo}

A expansão dos monocultivos de dendezeiros na Amazônia Paraense está inserida no contexto das agroestratégias comandadas pelo capital transnacional, as quais são incentivadas por políticas governamentais que estimulam a alocação de grandes investimentos exógenos, a partir de uma retórica ecológica, social e econômica para o desenvolvimento da região. Grandes companhias como a Biopalma/Vale, Archer Daniels Midland Company (ADM), Petrobrás Biocombustível, Galp Energia e Guanfeng Group instaladas nesta porção do território amazônico, dispõem de extensas faixas de terras apropriadas nos últimos anos. Os mecanismos de apropriação privada da terra pelo capital nacional e transnacional na microrregião de Tomé-Açu são analisados e revelam que esta vem se materializando em desacordo com o limite constitucional e outros dispositivos legais, caracterizando um processo de concentração de terras, que pode ser descrito como green grabbing, ancorado no tripé de argumentos sociotécnicos: o Zoneamento Agroecológico da Palma de Óleo (ZAE); a recuperação de áreas degradadas e a integração da agricultura familiar à cadeia agroindustrial.

Palavras-chave: Dendê. Capital transnacional. Apropriação de terras. Estrutura fundiária. Amazônia Paraense.

\section{Résumé}

L'expansion de la monoculture du palmier à huile dans l'état du Pará, en Amazonie, s'inscrit dans le contexte d'agro-stratégies contrôlées par le capital transnational, lesquelles sont encouragées par des politiques gouvernementales favorisant l'allocation 
de gros investissements exogènes en se basant sur une rhétorique écologique, sociale et de développement économique pour la région. De grandes entreprises comme Biopalma/Vale, Archer Daniels Midland Company (ADM), Petrobras Biofuel, Galp Énergie et Groupe Guanfeng se sont installées dans cette partie du territoire de l'Amazonie et se sont appropriées de vastes portions de terres au cours de dernières années. L'analyse des mécanismes d'appropriation privée de la terre par le capital national et transnational dans la micro-région de Tomé-Açu démontre que cela a été réalisé en désaccord avec les dispositifs constitutionnels et légaux, et met en évidence un processus de concentration de la terre, qui peut être qualifié de green grabbing, ancré sur le trépied d'arguments socio-techniques: le zonage agro-écologique du palmier à huile (ZAE) ; le rétablissement des zones dégradées et l'intégration de l'agriculture familiale à la chaîne agro-industrielle.

Mots-clés: Palmier à huile. Capital transnational. Appropriation de terres. Structure agraire. État du Pará. Amazonie.

\section{Introdução}

Dos estudos desenvolvidos sobre a expansão da dendeicultura nos últimos cinco anos na Amazônia, depreende-se que esta se encontra alinhada às estratégias engendradas por grandes empresas para incorporar novos estoques de terras à dinâmica do mercado internacional de commodities, que, por sua vez, se ancoram em políticas públicas que as subsidiam e as legitimam. Esta legitimação apoia-se principalmente na adoção e no discurso sobre padrões tecnológicos e em mecanismos diversos de apropriação de terras e territórios, aliada uma narrativa baseada em argumentos de cunho socioambiental. (BACKHOUSE, 2013, p. 7; NAHUM E SANTOS, 2014, p. 9).

Neste trabalho, pretendemos mostrar como esta ação concorre para a reconfiguração da estrutura fundiária do território, tomando para análise a variação do preço da terra e a invisibilidade das práticas de concentração de terras neste contexto. Reconfiguração e práticas eufemizadas sob expressões como "dinamização do mercado de terras" e "integração produtiva". Busca-se demonstrar como estas se dão ao largo da legislação brasileira, instalando-se um processo que alia expropriação e desimobilização de terras camponesas e pressiona áreas protegidas, como terras quilombolas e indígenas.

Com a expansão da dendeicultura reeditam-se pressupostos de outras políticas implementadas na Amazônia nas últimas quatro décadas, uma vez que no discurso oficial o monocultivo de palma e sua transformação em óleo para combustível emergem 
como uma das principais saídas para a redução das desigualdades sociais e a dinamização econômica da região de sua implantação, qualificada como economicamente estagnada e ambientalmente degradada.

Trata-se desta feita de uma ação pública sobre o território que apresenta como principais argumentos sociotécnicos o Zoneamento Agroecológico da Palma de Óleo (ZAE), elaborado pela Empresa Brasileira de Pesquisa Agropecuária (EMBRAPA), divulgado em 2010; a recuperação de áreas degradadas e a integração da agricultura familiar à cadeia agroindustrial (RAMALHO FILHO et al, 2010, p. 19) . É, pois, sobre este tripé que se verifica hoje, no estado do Pará, um dos processos mais violentos de concentração, de expropriação e de transferência de terras camponesas imobilizadas pela reforma agrária. Em consonância com autores que vêm estudando a temática (NAHUM, 2012, 2013, 2014; SAMPAIO, 2014; SOUSA, 2015; VIEIRA e MAGALHÃES, 2012) recorremos ao conceito marxiano de acumulação primitiva como inspirador da reflexão aqui apresentada e o conceito de green grabbing como descritor dos processos analisados (BACKHOUSE, 2013, p. 9; FAIRHEAD, LEACH e SCOONES, 2012).

A análise é realizada a partir de dados do Sistema Integrado de Monitoramento e Licenciamento Ambiental - Módulo Público (SIMLAM Público), gerenciado pela Secretaria Estadual de Meio Ambiente e Sustentabilidade do Pará; da Planilha de Preços Referenciais de Terras (PPRT), atualizada periodicamente pela Divisão de Obtenção de Terras e Implantação de Projetos de Assentamento do INCRA; do Sistema de Gestão Fundiária (SIGEF), gerenciado pelo INCRA; e dos atos administrativos expedidos pelo Congresso Nacional, que autorizam a concessão e alienação de terras públicas acima do limite constitucional, no Estado do Pará, obtidos a partir de pesquisa no portal de legislação do Senado Federal. A PPRT é um instrumento sistemático utilizado periodicamente pelo INCRA para averiguar a dinâmica do mercado de terras em regiões homogêneas, consistindo numa metodologia que envolve pesquisa nos cartórios de registros de imóveis, instituições de crédito, prefeituras municipais, sindicatos de trabalhadores rurais e sindicatos de produtores rurais. Os dados coletados são analisados e servem como subsídio para orientar as ações de obtenção de terras e de precificação do valor monetário dos lotes destinados aos assentados do Programa Nacional de Reforma Agrária (PNRA). Com os dados produzidos pelo INCRA e aqueles disponíveis no SIMLAM e no Senado Federal, evidencia-se, pois, como as empresas plantadoras de 
Monocultivos de dendezeiros, capital transnacional e concentração de terras na Amazônia Paraense
Elielson Pereira da Silva Sônia Barbosa Magalhães André Luís Assunção de Farias

dendezeiros (des) atendem ao dispositivo constitucional relativo à propriedade de terras no Brasil e aos regulamentos fundiários.

O trabalho está estruturado em três itens. No primeiro, intitulado "Principais empresas e a delimitação do território do dendê", apresentamos a distribuição das empresas de dendê no território, focalizando a microrregião de Tomé-Açu, na qual se concentram seis das grandes empresas. No segundo, "A concentração de terras", oferecemos uma espacialização das terras adquiridas que constam na base do Cadastro Ambiental Rural (CAR), conforme disponíveis no SIMLAM e analisamos a chamada "dinamização do mercado de terras", como evidência do processo de concentração. No último item, expomos os fundamentos que balizam o argumento aqui desenvolvido de que a concentração de terras está ancorada em processos de aquisição de terras invisíveis em registros legais.

\section{Principais empresas e a delimitação do território de expansão da dendeicultura}

De acordo com estudos de Nahum e Santos (2013, p. 76) a chegada de empresas produtoras de óleo de palma em escala industrial nesta porção do território paraense iniciou-se na década de 70, no contexto do II Plano de Desenvolvimento da Amazônia (PDA), sob a ditadura militar. Datam desta época a implantação da DENPASA e da AGROPALMA, nos municípios de Santa Bárbara do Pará (anteriormente distrito do município de Benevides) e Moju, respectivamente. A AGROPALMA continua atuando no espaço agrário regional. A DENPASA teve seus plantios de dendezeiros duramente atingidos pela doença conhecida como amarelecimento fatal, no período de 1974 a 1991, o que ocasionou a morte de mais de 100.000 plantas neste intervalo (VAN SLOBBE, 1988 apud BOARI, 2010, p. 153) e atualmente tem se limitado a produzir mudas de palma híbrida para comercialização. A maior parcela do território antes ocupado por esta empresa foi desapropriado para fins de reforma agrária em 2008, dando origem ao Projeto de Assentamento Abril Vermelho, numa área de 6.803 hectares, com capacidade para assentar 370 famílias.

Nos últimos anos, especialmente após o ZAE elaborado pela Embrapa (2010), verifica-se um movimento de empresas em direção ao nordeste do estado, estendendose por um arco formado desde os municípios de Santo Antônio do Tauá e Igarapé Açu, 
Monocultivos de dendezeiros, capital transnacional e concentração de terras na Amazônia Paraense
Elielson Pereira da Silva

Sônia Barbosa Magalhães André Luís Assunção de Farias

localizados no Salgado Paraense, passando por Bonito e Ourém, situados às proximidades da Rodovia BR-316 (Pará-Maranhão), percorrendo os municípios situados às margens da Rodovia BR-010 (Belém-Brasília) adentrando até Garrafão do Norte, seguindo para a microrregião de Tomé-Açu, cortada pelas rodovias estaduais PA 140, PA 252, PA 256, PA 150 e PA 151 e por fim, chegando aos municípios de Baião e Mocajuba, na região do Baixo Tocantins, de acordo com a figura 1, a seguir.

Figura 1 - Arco da expansão dos monocultivos de dendezeiros na Amazônia Paraense

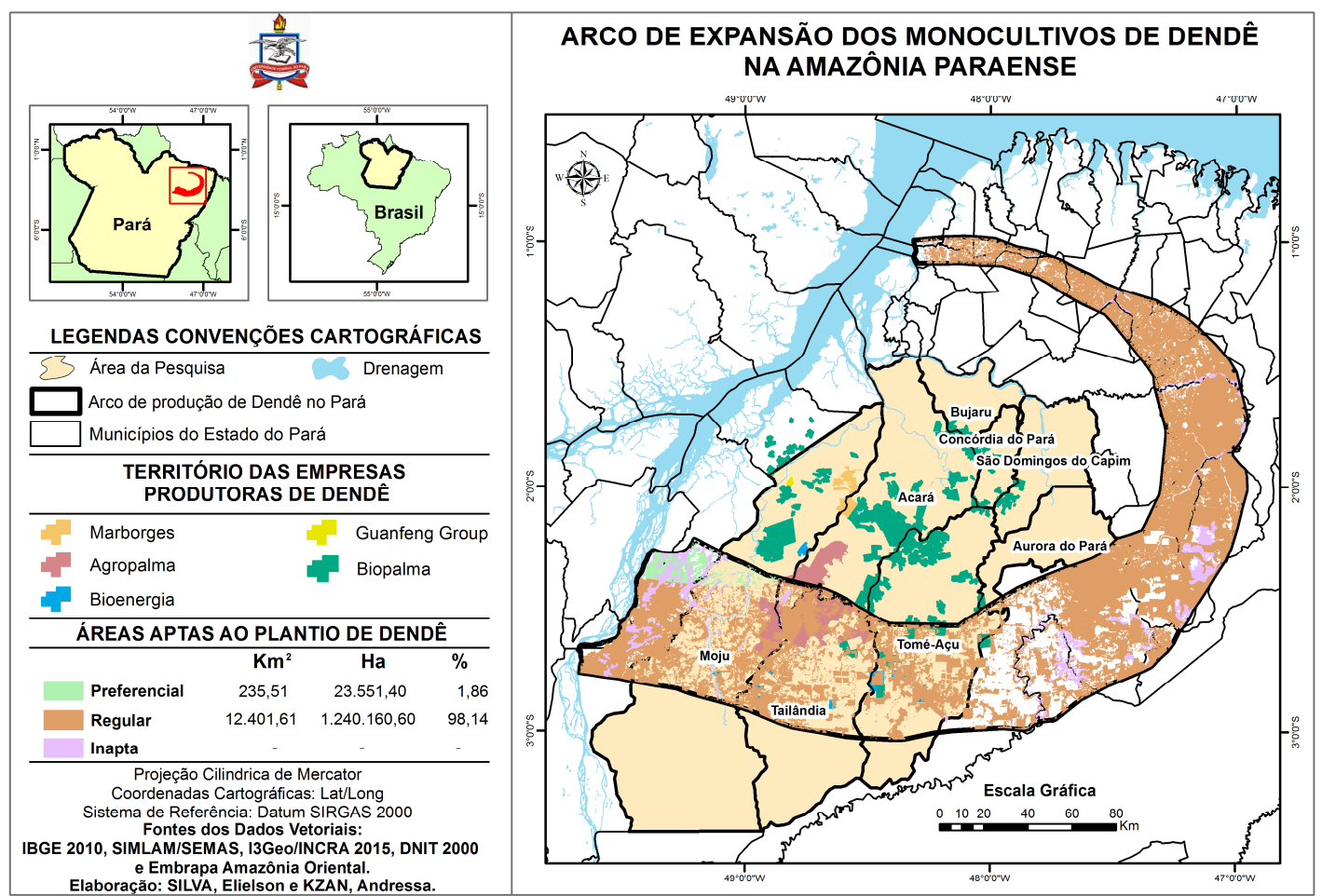

Fonte: EMBRAPA Amazônia Oriental, 29/09/2010; i3GEO/INCRA 2015, 20/05/2015; SIMLAM/SEMAS, 07/05/2015 e 30/06/2015.

Pode-se delimitar, assim, um território decorrente de uma nova ação pública, cujos arranjos institucionais encontram-se no Programa Nacional de Produção e Uso do Biodiesel (PNPB) de 2004 e no Programa de Produção Sustentável de Óleo de Palma, anunciado em 2010, e em instrumentos complementares. Na definição de Nahum e Malcher (2012, p. 3), configura-se um território como uma nova fronteira de recursos: "a fronteira da agricultura de energia".

Neste território, um conjunto de doze grandes empresas de capital nacional e transnacional, valendo-se de estímulos estatais (incentivos fiscais, infraestrutura e logística, 
Monocultivos de dendezeiros, capital transnacional e concentração de terras na Amazônia Paraense
Elielson Pereira da Silva

Sônia Barbosa Magalhães André Luís Assunção de Farias

marco regulatório para o setor, dentre outros) vêm produzindo plantations, concentração de terras, descampenização de comunidades rurais (NAHUM E SANTOS, 2014, p. 471) e proletarização. Monteiro (2013, p. 3330) aponta que uma parcela significativa desse novo proletariado consiste em filhos de agricultores que deixam de trabalhar com suas famílias, o que repercute sobre a capacidade laboral de tais unidades produtivas.

Neste trabalho será considerada parte deste território, que se configura nos municípios de Acará, Concórdia do Pará, Moju, Tailândia e Tomé Açu, que compõem a microrregião de Tomé-Açu. Nele encontram-se seis das grandes empresas e, entre estas, aquelas que apresentam maior concentração de terras.

Esta microrregião se estende por $23.704,4 \mathrm{~km}^{2}$, com uma população total de 287.618 pessoas, sendo que 49,8 dos habitantes residem nas cidades e 50,2\% nas áreas rurais, de acordo com o Censo Demográfico 2010, do Instituto Brasileiro de Geografia e Estatística (Tabela 1).

\section{Caracterização da microrregião de Tomé-Açu}

Tabela 1 - Área territorial e demografia na microrregião de Tomé-Açu

\begin{tabular}{|c|c|c|c|c|c|}
\hline$N^{0}$ ordem & Município & Área $\left(\mathrm{km}^{2}\right)$ & Pop. total & Pop. urbana & Pop. rural \\
\hline 1 & Acará & $4.343,8$ & 53.569 & 12.621 & 40.948 \\
\hline 2 & $\begin{array}{c}\text { Concórdia do } \\
\text { Pará }\end{array}$ & 690,9 & 28.216 & 15.088 & 13.128 \\
\hline 3 & Moju & $9.094,1$ & 70.018 & 25.162 & 44.856 \\
\hline 4 & Tailândia & $4.430,2$ & 79.297 & 58.713 & 20.584 \\
\hline 5 & Tomé-Açu & $5.145,4$ & 56.518 & 31.563 & 24.955 \\
\hline 5 & TOTAL & $23.704,4$ & 287.618 & 143.147 & 144.471 \\
\hline
\end{tabular}

Fonte: IBGE, 2010

Quando se analisa o contexto fundiário da microrregião, a partir das áreas protegidas, dos territórios tradicionais e dos assentamentos de reforma agrária, verifica-se a existência de 4 (quatro) terras indígenas das etnias Anambé e Tembé, 31 (trinta e um) comunidades quilombolas e 20 (vinte) projetos de assentamento, conforme a tabela 2.

Tabela 2 - Áreas protegidas, territórios quilombolas e projetos de assentamento na microrregião de Tomé-Açu

\begin{tabular}{|c|c|c|c|c|}
\hline $\mathbf{N}^{0}$ ordem & Nome & Área & Município & $\begin{array}{l}\text { Órgão } \\
\text { gestor }\end{array}$ \\
\hline 1 & $\begin{array}{c}\text { Terra Indígena } \\
\text { Anambé }\end{array}$ & $17.882,8329$ & Moju & Funai \\
\hline 2 & Terra Indígena Tembé & $1.075,1881$ & Tomé-Açu & Funai \\
\hline 3 & Terra Indígena Turé- & 146,9798 & Tomé-Açu & Funai \\
\hline
\end{tabular}


Monocultivos de dendezeiros, capital transnacional e concentração

Elielson Pereira da Silva de terras na Amazônia Paraense

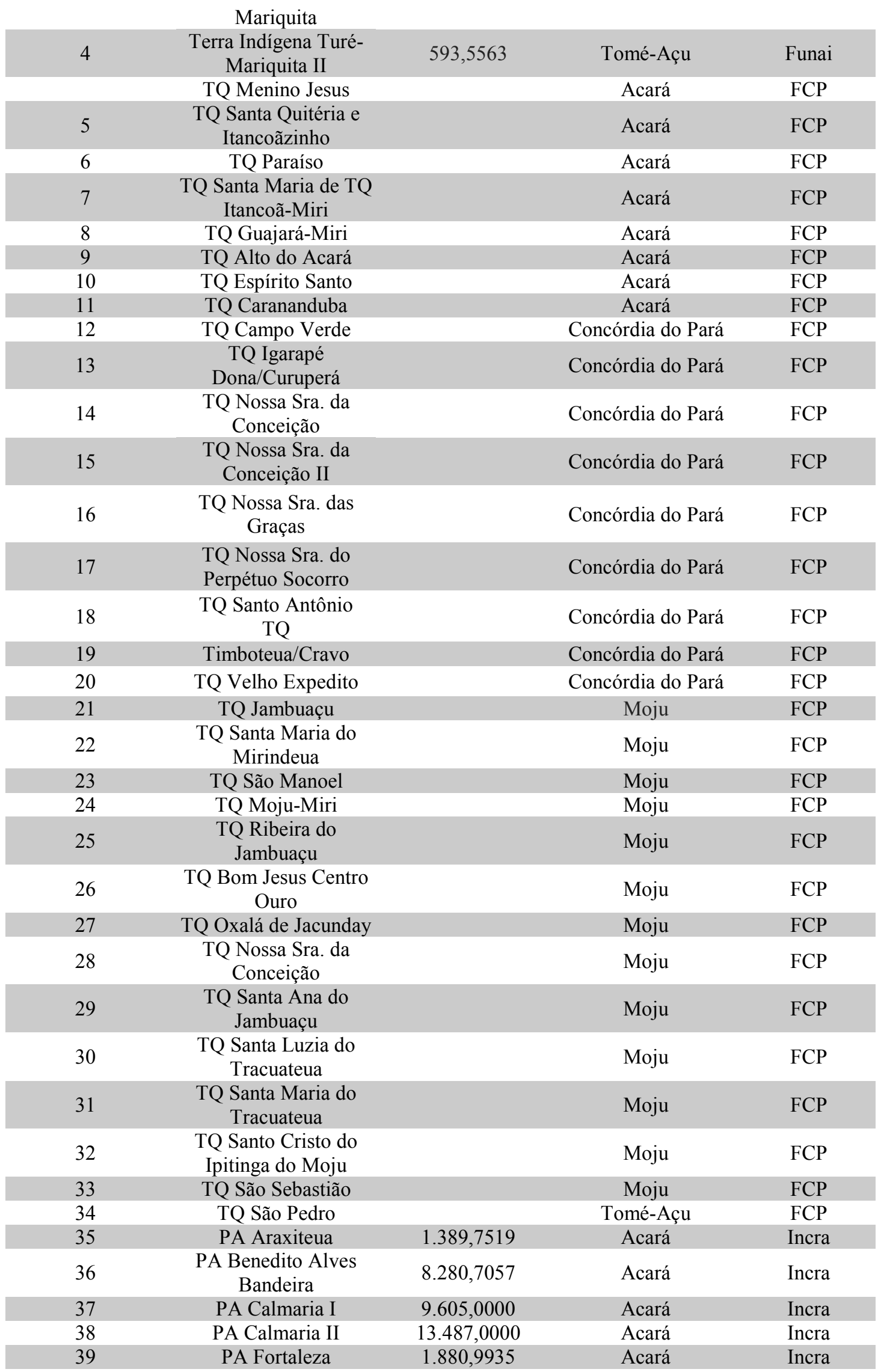


Monocultivos de dendezeiros, capital transnacional e concentração de terras na Amazônia Paraense
Elielson Pereira da Silva

Sônia Barbosa Magalhães

André Luís Assunção de Farias

\begin{tabular}{|c|c|c|c|c|}
\hline 40 & PA Nazare & $5.136,6010$ & Acará & Incra \\
\hline 41 & PA Santa Maria I e II & $4.256,4189$ & Acará & Incra \\
\hline 42 & PA São Lourenco & $1.258,7873$ & Acará & Incra \\
\hline 43 & PA Inácia & $2.662,7053$ & Concórdia do Pará & Incra \\
\hline 44 & PA Jutaí Mirim & $2.265,7652$ & Concórdia do Pará & Incra \\
\hline 45 & PA Nova Santa Maria & 910,9713 & Concórdia do Pará & Incra \\
\hline 46 & PA Rio Bujaru & $8.283,9790$ & Concórdia do Pará & Incra \\
\hline 47 & PA Maravilha & $8.650,0000$ & Moju & Incra \\
\hline 48 & PA Olho D’Água I & $9.670,8540$ & Moju & Incra \\
\hline 49 & PA Olho D’Água II & $8.111,7726$ & Moju & Incra \\
\hline 50 & PA Vale do Moju & $21.357,1324$ & Moju & Incra \\
\hline 51 & PA Miritipitanga & $4.356,0000$ & Tomé-Açu & Incra \\
\hline 52 & PA Tropicália & $4.356,0000$ & Tomé-Açu & Incra \\
\hline 53 & PA Serra Negra & $2.904,0000$ & Tailândia & Iterpa \\
\hline 54 & PE Borba Gato & $8.514,5100$ & Tailândia & Iterpa \\
\hline 55 & PE Pindorama & $3.974,3234$ & Tailândia & Iterpa \\
\hline
\end{tabular}

Fonte: FUNAI, 2015; Cadastro Nacional de Unidades de Conservação, 2015; Fundação Cultural Palmares, 2015; SIPRA/INCRA, 2015.

As empresas organizam-se no território constituindo um mosaico de capitais em uma monótona paisagem: a Biopalma/Vale; a Petrobrás Biocombustível, em parceria com a portuguesa Galp Energia; a norte-americana Archer Daniels Midland Company (ADM); o Guanfeng Group, da província de Shandong, na China; a Agropalma, empresa controlada pelo Banco Real; a Novacon Reflorestadora; e a Marborges, estas últimas de capital nacional.

Monteiro (2013, p. 3328) destaca que na microrregião de Tomé-Açu, acrescida dos municípios de Abaetetuba, Aurora do Pará e Bujaru, a qual se denomina Vale do Acará, estão localizados os plantios de dendê das empresas Biopalma/Vale (52.000 ha), Agropalma (45.000 ha), Petrobrás/Galp (25.000 ha), Marborges (6.000 ha) e Novacon (2.500 ha), totalizando 134.700 hectares, sendo que destes, 8.255 hectares são oriundos de contratos com a agricultura familiar. Esta expansão dos plantios de dendê no Pará vem sendo alavancada de forma expressiva e acelerada. Analisando as informações aduzidas pelo autor, infere-se que entre os anos de 2008 e 2012 houve um incremento de $107,7 \%$ na área plantada, passando de 65 mil hectares para 135 mil hectares nesse pequeno intervalo. De acordo com estimativas reportadas pelo autor, no final da década a previsão é de que os plantios de palma atinjam a marca de 750 mil hectares no Estado. Nahum (2014) e Backhouse (2013) também sinalizam que a expansão dos monocultivos de dendê tende a se intensificar na região.

Este processo de expansão do capital sobre o território foi estudado por Karl Marx no fim do século XIX na Inglaterra, que o identificou como um processo de 
acumulação primitiva - processo de expropriação dos camponeses de sua base fundiária e a consequente conversão destes em proletários, destituindo-os de seus meios de produção e transformando-os em massa assalariada a ser absorvida pelas indústrias que estavam nascendo e pelos grandes arrendatários detentores do espólio feudal alimentado com renda fundiária. (MARX, 1988, p. 252). Embora o conceito tenha sido utilizado para desnudar os estratagemas utilizados pelo capital durante a transição entre os regimes feudal e capitalista, pode ser utilizado hoje para pensar as novas formas de acumulação que se verificam especialmente na Amazônia. A reedição de práticas de expropriação indica que esta formulação pode inspirar os efeitos dos grandes projetos econômicos que recorrentemente vêm sendo implantados na Amazônia. Nesta linha interpretativa, Oliveira (2007, p. 11) assinala que assim se configura "uma espécie de acumulação primitiva permanente do capital, necessária ao seu desenvolvimento". Harvey (2013, p. 37), ao se reportar às atividades predatórias do modelo capitalista, caracterizadas por Marx como acumulação primitiva, afirma que este "é um processo internalizado contínuo" que promove "a despossessão dos direitos de terra, previdência social, dos direitos à pensão e à atenção à saúde, das qualidades ambientais, da própria vida". Na mesma linha Almeida e Acevedo Marín (2010, p. 145) interpretam a desterritorialização de comunidades tradicionais na Amazônia, provocadas pela expansão da fronteira agrícola, como por exemplo a produção de agrocombustíveis.

Marx observou a intensa e dramática desintegração do campesinato, mediante a expropriação de suas terras, por meio dos inclosures (cercamento das terras comunais), provocando a expulsão de milhares de famílias para os centros urbanos ou a conversão destes em assalariados rurais que passaram a vender sua força de trabalho para os grandes arrendatários. Como afirmara Marx (1988, p. 254), "uma massa de proletários livres ${ }^{1}$ como os pássaros foi lançada no mercado de trabalho" então emergente. As terras comunais destinadas à produção de alimentos, também chamadas de terras de lavoura foram transformadas em terras de pastagens para a criação de ovelhas, resultando na "usurpação despovoadora" dos territórios anteriormente usufruídos pelo campesinato, consoante as medidas adotadas durante a Revolução Gloriosa e posteriormente consagradas no denominado Clearing of States (clarear as propriedades, "limpá-las" de camponeses). 
Na microrregião de Tomé-Açu, Nahum e Santos (2014, p. 471) observam que o crescimento vigoroso dos plantios de dendê tem causado a descampenização de comunidades rurais, "com a formação de um campo sem camponeses", o que ocorre por meio da conversão da força de trabalho familiar em assalariados rurais para as grandes companhias agroindustriais de produção de óleo de palma.

Almeida e Acevedo Marín (2010, p. 148/149) afirmam que na ótica das grandes estratégias empresariais os povos e comunidades tradicionais são considerados como empecilhos para o avanço da fronteira agrícola. Para Almeida (2011, p. 28/33) as agroestratégias do capital se mobilizam sistematicamente no sentido de remover obstáculos jurídicos, institucionais, técnicos e normativos para assegurar a reestruturação do mercado de terras e a consequente conversão de áreas em monocultivos de larga escala.

Na microrregião de Tomé-Açu, à medida que os camponeses se subordinam ao agronegócio do dendê, seja por meio da venda de suas propriedades, do arrendamento fundiário ou do contrato com as companhias agroindustriais, acabam perdendo a autonomia sobre o principal meio de produção de que dispõem para se reproduzir física, cultural e socialmente: a terra.

Acevedo Marín e Backhouse (2014, p. 3/5) relatam que o avanço em larga escala do agronegócio do dendê nos municípios paraenses de Moju, Bujaru, Concórdia do Pará e São Domingos do Capim vêm promovendo o cercamento de territórios tradicionalmente ocupados por quilombolas e camponeses, através de variados mecanismos de apropriação da terra praticados por grandes empresas. De acordo com as autoras, esta região constitui o epicentro das transformações sociais inerentes às formas de representação e de luta dos trabalhadores.

A subordinação da gestão da produção resulta no que Marx (1988, p. 273) assim descreve: "antes a família camponesa produzia e processava os meios de subsistência e as matérias-primas que depois em sua maior parte ela mesmo consumia. Essas matériasprimas e esses meios de subsistência tornaram-se agora mercadorias". Ou seja, o que antes era produzido e consumido na unidade produtiva familiar camponesa agora tem que ser comprado pelos trabalhadores no mercado, estando sujeito às oscilações microeconômicas próprias desse novo ambiente. Monteiro (2013, p. 3332) reconheceu evidências de que a criação de empregos formais na dendeicultura, no período de 2002 a 
Monocultivos de dendezeiros, capital transnacional e concentração de terras na Amazônia Paraense
Elielson Pereira da Silva

Sônia Barbosa Magalhães André Luís Assunção de Farias

2011, afetou a produção de mandioca, considerada a principal base da dieta alimentar no Estado, e indica esse fator como um dos responsáveis pela pressão inflacionária nos preços da farinha no mencionado período. Este aspecto ainda é polêmico e merece ser melhor analisado, pois, os fatores climáticos, o ciclo produtivo e os preços nacionais podem ter afetado os preços locais e regionais.

\section{A concentração de terras}

As estratégias utilizadas pelas empresas para apropriação da terra vêm ocorrendo de três formas distintas e complementares: a) aquisição de imóveis rurais, notadamente fazendas e áreas de agricultura familiar, embora o Programa vede expressamente a compra de lotes de agricultores; b) arrendamento de imóveis rurais, principalmente fazendas com pastos abandonados; c) a transferência das terras da reforma agrária mediante o sistema de "integração".

As informações sobre estas modalidades de aquisição de terras, no entanto, não estão plenamente disponíveis. Mesmo o total da área já monopolizada não é de fácil acesso. Para este trabalho, tentamos dimensioná-la utilizando dados já disponíveis na literatura e a base do SIMLAM Público, conforme Tabela 3 a seguir.

Tabela 3 - Concentração de Terras na microrregião de Tomé Açu - Pará

\begin{tabular}{lccc}
\hline \multicolumn{1}{c}{ Empresa } & $\begin{array}{c}\text { Área total cf. } \\
\text { SIMLAM (ha) }\end{array}$ & $\begin{array}{c}\text { Área de uso } \\
\text { alternativo estimada } \\
\text { cf. literatura (ha) }\end{array}$ & $\begin{array}{c}\text { Área estimada cf. } \\
\text { literatura, com } \\
\text { reserva legal (ha) }\end{array}$ \\
\hline $\begin{array}{l}\text { Petrobrás } \\
\text { Biocombustível e Galp }\end{array}$ & $98.000,00$ & $196.000,00$ \\
Energia & $12.557,13$ & & \\
Biopalma/Vale & $240.690,22$ & $80.000,00$ & $160.000,00$ \\
ADM & sem informação & $12.000,00$ & $24.000,00$ \\
Agropalma & $107.373,07$ & $43.000,00$ & $107.000,00$ \\
Marborges & $17.782,59$ & $6.000,00$ & - \\
Guanfeng Group & 903,1553 & - & - \\
Novacon & sem informação & $2.500,00$ & - \\
Reflorestadora & & & \\
\hline Fonte: BASA (2012, p. 4-5); (NAHUM e SANTOS, 2013, p. 78); MONTEIRO (2013, p. 3328); \\
SIMLAM Público, acesso em 07/05/2015 e 30/06/2015.
\end{tabular}

A Petrobrás Biocombustível possui dois empreendimentos diferentes, sendo um conduzido pela Belém Bioenergia, uma holding criada em parceria com a Galp Energia e prevê o plantio de 50 mil hectares, em quatro pólos (Tomé-Açu, Tailândia e outros a serem 
definidos), mediante contrato com a agricultura familiar e com médios e grandes produtores, assim como por meio de arrendamento de áreas entre 300 hectares e 1.000 hectares. O segundo, denominado Projeto Pará, tem o objetivo de abastecer o mercado da região Norte e visa a implantação de 48 mil hectares de plantio, distribuídos entre contrato com a agricultura familiar e com produtores independentes. Considerando os preceitos do Novo Código Florestal e do Zoneamento Ecológico-Econômico da Calha Norte e do Leste do Pará, relativamente ao tamanho da Reserva Legal (RL) dos imóveis rurais dessa região, estima-se que a área total a ser apropriada pela Petrobrás Biocombustível atingirá o montante de 196 mil hectares (BASA, 2012, p. 4; NAHUM E SANTOS, 2013, p. 78).

Os plantios da Biopalma, empresa com capital social controlado pela multinacional Vale, estão dispostos em quatro pólos nos municípios de Acará, Concórdia do Pará, Moju e Tomé-Açu. A empresa pretende abranger uma área de 80 mil hectares, sendo 60 mil hectares oriundos de áreas adquiridas pela empresa e 20 mil hectares mediante contrato com a agricultura familiar, projetando-se o envolvimento de 2 mil famílias. Quando incluímos o cálculo da Reserva legal (RL), compreendendo que os plantios se constituem como área de uso alternativo do solo, verificamos que esta companhia terá o controle sobre 160 mil hectares no território (BASA, 2012, p. 4; NAHUM E SANTOS, 2013, p. 78). Por meio de pesquisa efetuada junto ao SIMLAM Público no dia 07/05/2015, identificou-se 105 (cento e cinco) imóveis pertencentes a Biopalma, com área equivalente a 112.451,96 hectares, distribuídas pelos municípios da Amazônia Paraense situadas na faixa preferencial para a expansão dos plantios de dendê. Entretanto, 54 dias após a primeira consulta ao sistema detectou-se um aumento abrupto do número de imóveis rurais registrados em nome daquela companhia, passando de 105 para 238, o que representa um crescimento de 126,67\%. Em consequência desse fato, o montante de área apropriada pela Biopalma cresceu 114,14\% neste curtíssimo espaço de tempo, totalizando 240.690,22 hectares.

No caso da empresa norte-americana ADM, as informações indicam uma expectativa de 12 mil hectares de plantios, distribuídos em 6 mil hectares em áreas arrendadas e 6 mil hectares sob contrato com a agricultura familiar. Considerando a reserva legal, concluímos que 24 mil hectares de terra serão incorporados a esse empreendimento. BASA (2012, p. 5) e Nahum e Santos (2013, p. 78), indicavam que o planejamento da companhia previa a instalação de uma planta industrial no município 
de São Domingos do Capim, entretanto, nossa pesquisa de campo revelou que o local foi transferido para o município vizinho de Mãe do Rio, situado às margens da Rodovia BR-010 (Belém-Brasília). Ressalte-se que nenhum imóvel rural arrendado e/ou adquirido por esta empresa está registrado em seu nome na base do Cadastro Ambiental Rural, o que impossibilita a espacialização destas áreas na malha fundiária regional.

A Agropalma, empresa controlada anteriormente pelo Banco Real, é uma das primeiras companhias produtoras de dendê que se instalaram na Amazônia paraense, precisamente no início da década de 80 (VIEIRA, 2015, p. 6). Segundo Monteiro (2013, p. 3328), a empresa possui 45 mil hectares de dendê implantados, sendo 43.200 hectares em área própria e 1.800 hectares mediante contrato com agricultores familiares e assentados de reforma agrária do município de Moju. Segundo Andrade (2009, p. 67), a Agropalma concentra 107 mil hectares de terra, situadas nos municípios de Acará, Moju, Tailândia e Tomé-Açu, sendo que destes 64 mil seriam reservas florestais e o restante destinado à produção de óleo de palma. Pesquisa efetuada junto ao SIMLAM Público validou essa informação.

O Guanfeng Group Company, estatal chinesa da província de Shandong, instalouse no município de Moju por volta do ano de 2010. Possui plantios de dendê numa área própria inicial de 600 hectares, conforme reportagem do Portal BiodieselBR, de 02/05/2012. Com base em consulta junto ao SIMLAM Público identificou-se uma fazenda adquirida por esta empresa no município de Moju, com área de 903 (novecentos e três) hectares. No entanto, missões do Governo do Pará e de parlamentares da Assembleia Legislativa do Estado tem visitado a China para aumentar a inserção desta companhia neste e em outros empreendimentos no estado. Em conformidade com o ordenamento jurídico brasileiro, qualquer aquisição de imóvel rural por estrangeiro deve ser submetida à análise e deliberação do órgão fundiário federal, com a consequente publicação do ato no Diário Oficial da União. No entanto, não identificou-se nenhum ato expedido pelo Instituto de Terras do Pará, pelo Governador do Estado ou pela Assembleia Legislativa do Pará, nos meios de comunicação oficial de publicação dos atos administrativos (Imprensa Oficial do Estado -IOEPA) autorizando a concessão e alienação de terras públicas em favor do grupo empresarial estrangeiro.

A Marborges, empresa de capital nacional instalada na região no início da década de 90, está situada nos municípios de Acará, Moju e Garrafão do Norte, com três 
imóveis rurais que somam 17.782,59 hectares, localizados em Moju, conforme dados obtidos junto ao SIMLAM Público.

Os arrendamentos fundiários para a produção de óleo de palma têm sido um instrumento utilizado principalmente pelas empresas ADM e Petrobrás Biocombustível, mediante contratos de 25 anos, prorrogáveis por igual período, e as terras envolvidas nessas operações de mercado normalmente são antigas fazendas, numa indicação clara de migração do capital agrário e agroindustrial entre incentivos físcais e econômicofinanceiros propugnados por políticas públicas.

A transferência das terras da reforma agrária para o monocultivo do dendê vem ocorrendo também sutil e estrategicamente, por intermédio da "integração" dos assentados, comprometendo a maioria absoluta das áreas de uso alternativo para uma atividade cuja lógica é externa e diversa da lógica de organização do trabalho e de gestão da unidade de produção de base familiar ou camponesa. Nesta perspectiva, o controle sobre o uso da terra pelas próximas três décadas passa a ser exercido pelo agronegócio do dendê, numa relação de assimetria, coerção dissimulada e transferência total dos riscos da atividade econômica em desfavor dos agricultores familiares.

A figura 2 identifica a espacialização de áreas de apenas quatro das empresas produtoras de óleo de palma na Amazônia Paraense, mediante consulta aos dados do Sistema Integrado de Monitoramento e Licenciamento Ambiental - Módulo Público (SIMLAM Público), gerenciado pela Secretaria Estadual de Meio Ambiente e Sustentabilidade do Pará. Observa-se que das companhias instaladas neste território, a ADM, situada nos municípios de Santa Maria do Pará, São Miguel do Guamá, Irituia, Mãe do Rio, São Domingos do Capim, Aurora do Pará, Capitão Poço; e a Mejer Agroflorestal, localizada nos municípios de Ourém, Garrafão do Norte e Bonito, não aparecem no mapa porque os imóveis rurais apropriados por essas empresas não constam na base do Cadastro Ambiental Rural (CAR) e consequentemente estão fora do SIMLAM. 
Monocultivos de dendezeiros, capital transnacional e concentração de terras na Amazônia Paraense
Elielson Pereira da Silva

Sônia Barbosa Magalhães André Luís Assunção de Farias

Figura 2 - Territorialização de empresas produtoras de óleo de palma na Amazônia Paraense e áreas protegidas na região pesquisada

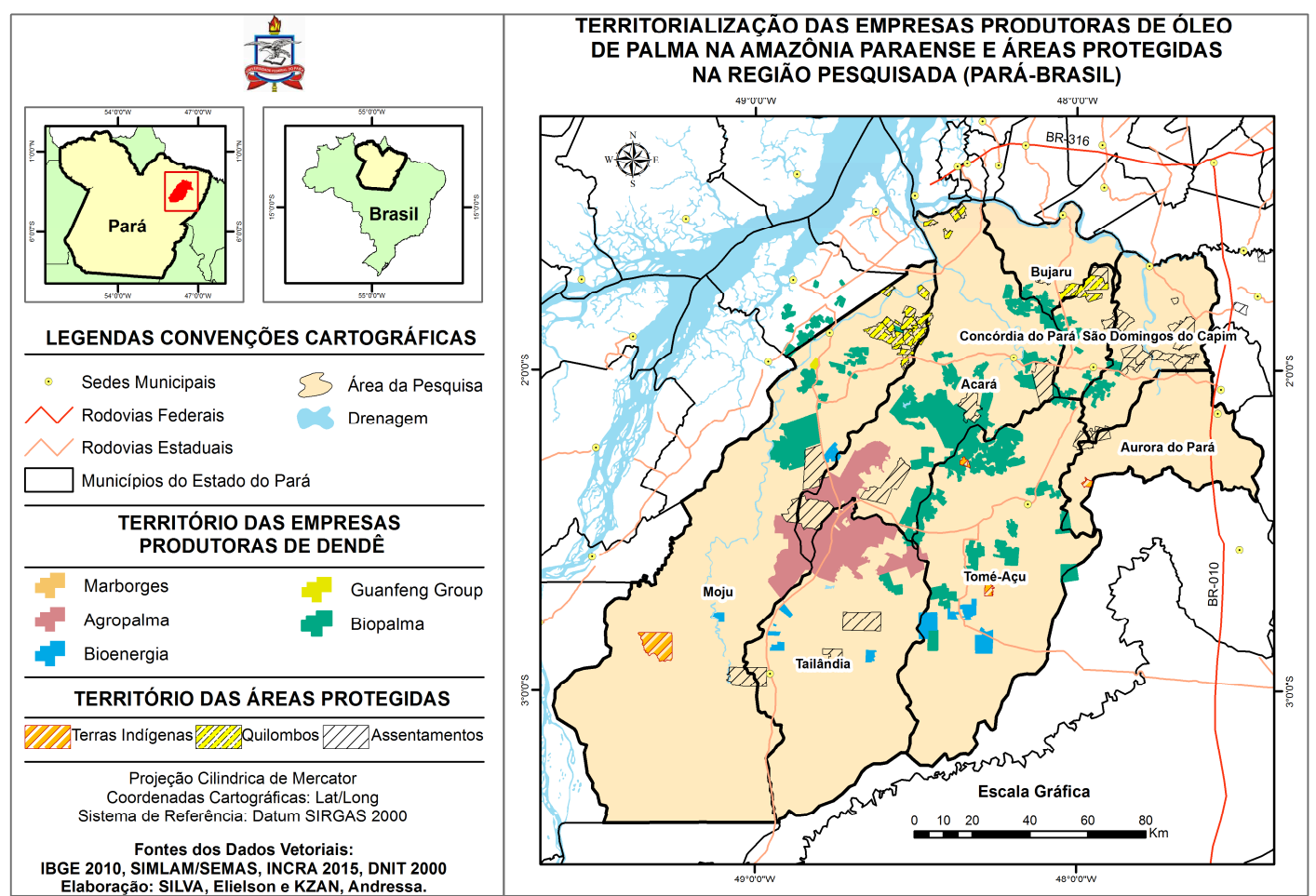

Fonte: SIMLAM/SEMAS, 07/05/2015 e 30/06/2015; i3Geo/INCRA, 20/06/2015.

Chama atenção a contradição que existe entre a agressiva concentração de terras que se verifica no território e se visibiliza na paisagem e na "dinamização" do mercado de terras e a sua invisibilidade nos registros legais.

Outro aspecto evidenciado na figura 2 refere-se ao cercamento de territórios tradicionalmente ocupados pelo avanço do agronegócio do dendê, tais como terras indígenas, comunidades de remanescentes de quilombos e áreas de agricultura familiar ou camponesa, confirmando o que Acevedo Marín e Backhouse (2014) enunciavam com base em pesquisas realizadas no âmbito do Projeto Nova Cartografia Social da Amazônia.

\section{A "dinamização" do mercado de terras é solidária à concentração fundiária}

No contexto da expansão dos plantios de dendê na Amazônia paraense, notadamente nos municípios que compõem a microrregião de Tomé-Açu, tem-se observado um aquecimento sem precedentes das transações no mercado de terras. Analisamos esse aquecimento por meio do comportamento do mercado de terras a partir 
Monocultivos de dendezeiros, capital transnacional e concentração de terras na Amazônia Paraense
Elielson Pereira da Silva

Sônia Barbosa Magalhães

André Luís Assunção de Farias

de uma série histórica que compreende o período anterior aos programas governamentais de incentivo à produção de óleo de palma até o período mais recente.

Com base nas informações constantes nas Planilhas de Preços Referenciais de Terras elaboradas pela Superintendência Regional do INCRA no Pará - SR (01) nos anos de 2000, 2003, 2005, 2008, 2009, 2010 e 2013 foi possível identificar a evolução do preço do hectare da terra nos municípios situados na microrregião de Tomé-Açu. Na metodologia utilizada pelo INCRA foi acrescentado o município de Bujaru que, embora esteja fora da microrregião, também é alvo da expansão da dendeicultura. Ainda que nos anos de 2001, 2002, 2004, 2006, 2007, 2011, 2012 e 2014 aquela instituição não tenha realizado a pesquisa, a série disponível não prejudica a análise (Fig. 1).

Figura 3 - Dinâmica do mercado de terras na microrregião de Tomé-Açu, 2000 a 2013

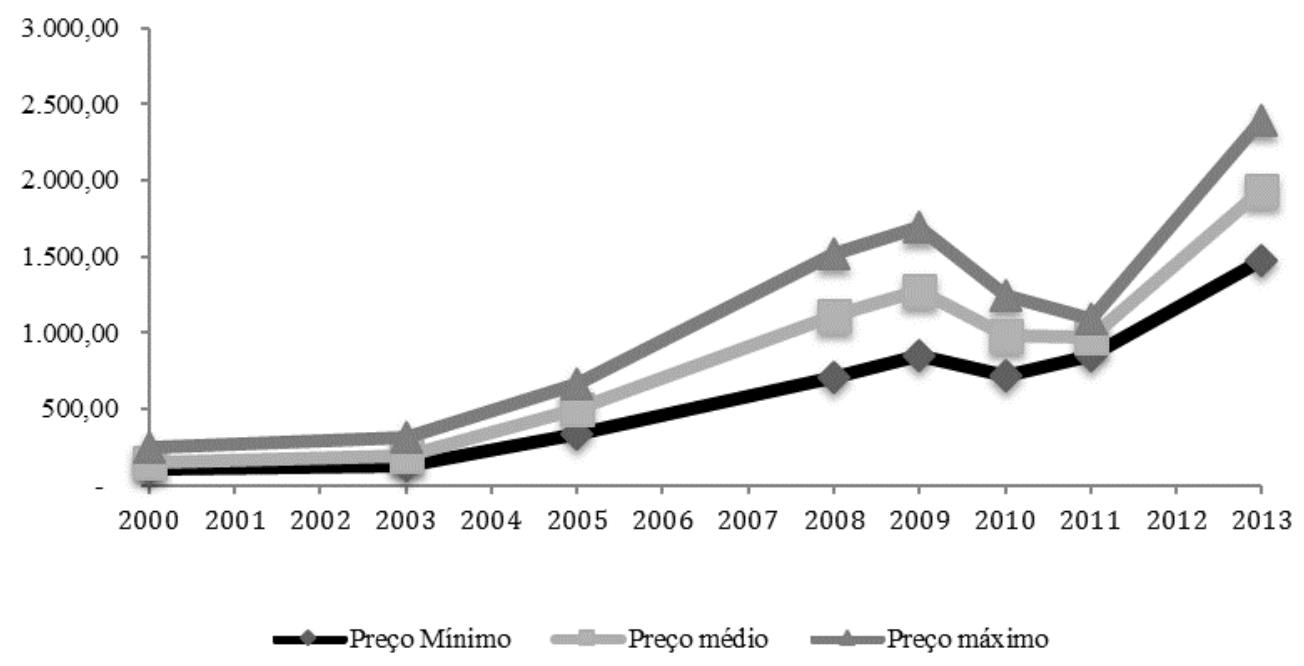

Fonte: INCRA, 11/02/2015.

Os preços mínimo, médio e máximo do hectare da terra são determinados pelo valor total dos imóveis rurais, considerando as benfeitorias existentes e o valor da terra nua (VTN). Os estudos de Marx sobre a renda fundiária, em sua crítica da Economia Política, conforme aludem Harvey (2010) e Oliveira (2007), postulam que as terras com menor fertilidade e cuja localização esteja mais distante dos núcleos urbanos tendem a ser menos valorizadas e com isso apropriam pouca renda diferencial. Por outro lado, aquelas situadas em regiões mais férteis naturalmente e melhor localizadas em relação 
aos centros dinâmicos têm a capacidade de apropriar a maior fatia da renda fundiária diferencial gerada pela terra.

O ZAE do dendê aprovado em 2010 definiu as classes preferencial, regular, marginal e inapta para a expansão da dendeicultura no país, prioritariamente na Amazônia.

Quando se examinam as oscilações no preço mínimo do hectare da terra no período compreendido, percebe-se que nos intervalos entre 2003/2005, 2005/2008 e $2011 / 2013$ ocorreram as maiores variações positivas neste mercado de terras $(164,0 \%$, $114,0 \%$ e 74,6\%, respectivamente). Vê-se que em 2004 quando foi lançado o Programa Nacional de Produção e Uso do Biodiesel e a partir deste marco a corrida pela apropriação de terras se intensifica - naquele momento já havia a especulação de que grandes investimentos privados para expansão da produção de óleo de palma seriam feitos nesse território. Nos anos que antecederam o lançamento do Programa de Produção Sustentável de Óleo de Palma o ritmo das transações imobiliárias enfraqueceu, principalmente entre 2009 e 2010. Após o lançamento do Programa, novamente os preços do hectare da terra voltaram a subir de forma progressiva (Figura 1).

No que se refere às variações no preço médio do hectare da terra nos 13 anos da série histórica, verifica-se novamente que nos intervalos de 2003/2005, 2005/2008 e 2011/2013 a sobrevalorização das terras se deu de forma mais intensa $(163,2 \%, 122, \%$ e 99,9\%, respectivamente). Entre os anos de 2009/2010 e 2010/2011 o preço médio teve uma ligeira queda $(-22,8 \%$ e $-1,5 \%)$, o que pode indicar um reequilíbrio entre oferta e demanda dentro de um mercado exorbitantemente aquecido.

Com respeito ao comportamento do preço máximo do hectare da terra, observase que nos intervalos entre 2003/2005, 2005/2005 e 2011/2013 ocorreu o crescimento mais intenso deste mercado fundiário na microrregião $(109,5 \%, 129,2 \%$ e 119,6\%). Aqui se verifica que as áreas mais "valorizadas", que a nosso ver são aquelas situadas na faixa preferencial para a expansão dos plantios de dendê, sofreram uma forte sobrevalorização no período, indicando que grandes volumes de capitais se dirigiram para a aquisição dessas terras. Entre os anos 2009/2010 e 2010/2011 houve uma queda no preço máximo do hectare, de $-26,5 \%$ e $-12,5 \%$, respectivamente, que pode igualmente ser atribuída ao reequilíbrio de preços no mercado. 
A reflexão crítica sobre a chamada "dinamização" do mercado de terras evoca os aportes de Polanyi (2000, p. 93) quando assinala que "o trabalho e a terra nada mais são do que os próprios seres humanos no qual consistem todas as sociedades, e o ambiente natural no qual elas existem. Incluí-los no mecanismo de mercado significa subordinar a substância da própria sociedade às leis de mercado". O autor acrescenta que a ruptura violenta que marcou a transição da sociedade moderna para uma economia de mercado, por meio de um sistema autorregulado, foi determinada, sobretudo, pela "transformação do trabalho e da terra como mercadorias, como se tivessem sido produzidos para a venda" (POLANYI, 2012, p. 53).

\section{Concentração fundiária e green grabbing}

Ao investigar a expansão da dendeicultura na Amazônia, utilizando uma abordagem focada no green grabbing ${ }^{2}$ como maneira de interpretar as estratégias empregadas pelo capital transnacional para ampliar a fronteira econômica com base num discurso ecológico, Backhouse (2013, p. 11) aponta que o polêmico conceito de “áreas degradadas" se constitui como uma forma pós-moderna de apropriação da terra e dos recursos naturais, por meio do controle e uso da terra pelo agronegócio.

Almeida e Acevedo Marín (2010, p. 146) asseveram que há em curso na Amazônia um conjunto de agroestratégias do grande capital para promover a desterritorialização de territórios tradicionais, mediante a remoção de obstáculos jurídicos, institucionais e normativos que possibilitem a incorporação de novos estoques de terras ao mercado e o controle dos conhecimentos dos recursos genéticos. Essa dinâmica é influenciada pela oscilação dos preços de commodities e pelos negócios ditos "sustentáveis", representados pelos agrocombustíveis.

A tentativa sistemática de flexibilização da legislação vigente nas instâncias parlamentares e judiciais representa uma ameaça clara aos direitos territoriais, estimula a intensificação das tensões sociais no campo e aumenta a pressão sobre as florestas.

Almeida e Acevedo Marín (2010, p. 150) identificam que em médio prazo há uma clara intenção de "retirar da imobilização recursos naturais que passam a se tornar objeto de compra e venda. Destruiriam assim o que foi conquistado e formalmente reconhecido". Essa possibilidade incluiria a destinação de compensações aos povos e 
Monocultivos de dendezeiros, capital transnacional e concentração de terras na Amazônia Paraense
Elielson Pereira da Silva Sônia Barbosa Magalhães André Luís Assunção de Farias

comunidades tradicionais afetados pelas estratégias triunfalistas do agronegócio. Incluise nessa perspectiva a sofisticada estratégia utilizada pelas agroindústrias de dendê em promover a "integração" de assentados de reforma agrária da microrregião de ToméAçu, visando converter em monocultivos as terras destinadas àquela finalidade social.

Na Amazônia, no estado do Pará e em especial na microrregião de Tomé-Açu, a corrida pela apropriação de terras após o lançamento do Programa Nacional de Produção e Uso do Biodiesel (PNPB) em 2004 e principalmente depois do Programa de Produção Sustentável de Óleo de Palma, anunciado em 2010, tem se concretizado à margem dos instrumentos jurídicos legais de regulação de uso, de apropriação e de troca da mercadoria terra.

A concentração da estrutura fundiária e da propriedade da terra tem sido a principal marca que acompanha o capitalismo agrário brasileiro em seu processo de acumulação. Guimarães (1968), Prado Jr. (1960), Vinhas (2005), Hoffmann e Ney (2010) reportam que a desigualdade fundiária, marca inerente à formação econômica do Brasil, se mantém praticamente inabalável ao longo do tempo. Na Amazônia, não tem sido diferente.

No caso amazônico, o Estado brasileiro tem exercido o papel de principal sujeito na indução de processos exógenos de ocupação e uso do território, o que tem intensificado a apropriação dos recursos naturais e os conflitos socioambientais daí decorrentes. Loureiro e Pinto (2005) mostram como a partir da década de 60 o governo federal passou a atrair intencionalmente o grande capital para a Amazônia, por meio de incentivos fiscais, investimentos em obras de infraestrutura, financiamentos a juros subsidiados e concessões de terra, com o objetivo de integrar a região aos mercados nacional e internacional. Iniciativas que se reeditam nas políticas governamentais voltadas à expansão da dendeicultura no estado do Pará, cf. Backouse (2013) e Nahum (2014). Reeditam-se também artifícios ou meios ilícitos usados à época, conforme apontam Loureiro e Pinto (2005), Benatti (2008), Treccani (2006) e Oliveira (2007).

Levantamentos realizados pelo Instituto Nacional de Colonização e Reforma Agrária - INCRA e pelo Instituto de Terras do Pará - ITERPA desde a década de 90, além de pesquisas desenvolvidas por estudiosos da matéria e denúncias de movimentos sociais organizados apontam a proporção tomada pela grilagem de terras no Estado do Pará, o que, inclusive, já ensejou a criação de Comissões Parlamentares de Inquérito no 
Monocultivos de dendezeiros, capital transnacional e concentração de terras na Amazônia Paraense
Elielson Pereira da Silva Sônia Barbosa Magalhães André Luís Assunção de Farias

Congresso Nacional e na Assembleia Legislativa do estado na década de 1990. Treccani (2006) aponta a participação efetiva, conivente e criminosa de muitos cartórios de registros de imóveis: sesmarias e títulos de posse "caducos" foram registrados como se tivessem sido regularmente legitimados, áreas constantes em escrituras públicas de origem duvidosa foram ampliadas astronomicamente, títulos fraudulentos sem a comprovação do destaque do patrimônio público para o particular foram fabricados no intento de justificar o domínio de extensas áreas, dentre outras aberrações. Destaque-se o caso emblemático de Moju - hoje uma das principais localizações da dendeicultura, cuja área registrada em cartório é 11,7 vezes o tamanho da superfície territorial do município.

Diante de tamanho caos fundiário, em 2006, a Corregedoria de Justiça das Comarcas do Interior (CJCI), do Tribunal de Justiça do Estado do Pará (TJ/PA), editou o Provimento $n^{\circ} 13 / 2006$, determinando o bloqueio de 6.102 matrículas com indícios contundentes de irregularidades, as quais representam uma área de 110 milhões de hectares, equivalente a $88 \%$ do território do Estado. Os registros alcançados pelo aludido ato administrativo foram aqueles efetuados a partir de 16/07/1934, em desacordo com a determinação constitucional que impôs limites para a concessão e alienação de terras públicas. Observe-se que a Constituição Federal de 1934 (art. 130) estabeleceu este limite em 10.000 (dez mil) hectares sem autorização do Senado Federal. A Constituição de 1937 (art. 155) manteve esse parâmetro; a Constituição de 1946, por meio da Emenda Constitucional $n^{\circ}$ 10, de 09/11/1964 (art. $6^{\circ}$ ) reduziu esse limite para 3.000 (três mil) hectares, mantido pela Constituição de 1967 (art. 154) e reduzido na Constituição Federal de 1988 para 2.500 (dois mil e quinhentos) hectares (art. 188, $\S 1^{\circ}$ ). Desta forma, os registros em cartório com área superior ao limite constitucional, sem a devida anuência do Congresso Nacional, são considerados nulos de pleno direito (CORREGEDORIA DE JUSTIÇA DAS COMARCAS DO INTERIOR, 2006).

Diante do quadro apontado, em 2007, por solicitação da Federação dos Trabalhadores na Agricultura do Pará (FETAGRI), o Tribunal de Justiça do Estado, instituiu a Comissão Permanente de Monitoramento, Estudo e Assessoramento das questões ligadas à Grilagem, composta por várias instituições públicas e organizações da sociedade civil. Estudos realizados por aquela Comissão durante o período de 5 (cinco) anos revelaram números impressionantes a respeito das fraudes fundiárias engendradas por pretensos proprietários, em conluio com a ardilosa ação de cartorários. 
Monocultivos de dendezeiros, capital transnacional e concentração de terras na Amazônia Paraense
Elielson Pereira da Silva Sônia Barbosa Magalhães André Luís Assunção de Farias

Identificou-se a existência de 9.124 registros acima do limite constitucional, que abrangem 489.887.364,39 (quatrocentos e oitenta e nove milhões, oitocentos e oitenta e sete mil, trezentos e sessenta e quatro hectares e trinta e nove ares), os quais correspondem a 3,9 vezes o tamanho do território paraense.

A Comissão decidiu propor à Corregedoria de Justiça das Comarcas do Interior o cancelamento administrativo dos 6.102 registros irregulares identificados pelo Provimento CJCI n ${ }^{\circ} 13 / 2006$, com base em dispositivos da legislação vigente e em jurisprudências do Conselho Nacional de Justiça (CNJ) que permitem a adoção desse mecanismo, invertendo o ônus da prova em desfavor de quem se intitula proprietário de imóveis rurais com origem duvidosa. Ocorre que a CJCI/TJ e o Conselho de Magistratura do Tribunal rechaçaram a proposição, arguindo que a adoção de tal medida colidiria com o devido processo legal. Resumidamente, o entendimento defendido pelos dois órgãos demandados é que o cancelamento só seria possível mediante decisão judicial transitada em julgado, através de processos individualizados.

Mediante as circunstâncias apresentadas, a Comissão decidiu recorrer ao Conselho Nacional de Justiça, órgão com competência legal para reformar a decisão do Tribunal de Justiça do Pará. Assim, em agosto de 2010, o Corregedor Nacional de Justiça do CNJ, Gilson Dipp, acatou o pedido de providências e determinou o cancelamento administrativo de 5.398 matrículas com áreas superiores ao limite constitucional.

Após essa medida, em setembro de 2010, o Tribunal de Justiça do Pará editou o Provimento CJCI/TJE n ${ }^{\circ}$ 02/2010 que ensejou o cancelamento administrativo de 9.124 matrículas bloqueadas pelo Provimento CJCI/TJE no 13/2006, alcançando milhares de registros irregulares espalhados pelo Estado, inclusive na região onde o grande capital induz a expansão da dendeicultura.

Essa abordagem se mostra relevante na medida em que o território preferencial para o avanço dos monocultivos de dendezeiros na Amazônia Paraense coincide com municípios onde a grilagem se constituiu como o principal mecanismo de apropriação irregular das terras, tais como Acará, Moju e Tomé-Açu, o que engendrou uma estrutura fundiária marcada por graves conflitos agrários entre fazendeiros, camponeses e comunidades tradicionais. 
Na década de 1980 várias companhias agroindustriais do dendê se instalam na região, atraídas pelos vantajosos incentivos fiscais concedidos pela Sudam e pelas operações de crédito rural alavancadas pelo Banco da Amazônia. É o período da "modernização conservadora" e o ideário da industrialização da agricultura permeia a agenda institucional e acadêmica e o imaginário de parcelas da sociedade. Terras e territórios são apropriados para os interesses do grande capital, sob a forma de grandes projetos homogeneizantes, sem identidade com o entorno em que se estabelecem. Formam-se os enclaves, eclodem os conflitos, as expropriações, as contradições do sistema hegemônico, não obstante a resistência de sujeitos sociais que diante da pressão em que se veem envolvidos organizam novas formas de enfrentamento (DELGADO, 2014, HÉBETTE, 2004, SACRAMENTO, 2007). É nesse contexto que as primeiras empresas do dendê fincam raízes em municípios como Benevides (hoje Santa Bárbara do Pará), Moju, Acará, Igarapé-Açu e Santo Antônio do Tauá.

Com a chegada das grandes companhias produtoras de óleo de palma as transformações no espaço agrário se intensificaram e os mecanismos empreendidos para apropriação dos recursos naturais se fundamentaram topográfica e juridicamente em uma estrutura fundiária forjada em décadas anteriores, cujos traços principais consistiram no emprego da força, nas relações de poder local em desfavor dos camponeses, na contumaz adulteração de registros imobiliários pelos cartórios da região e nos conflitos pela posse e propriedade das terras. Prova disso é que vários cartórios de registros de imóveis dessa microrregião encontram-se interditados por determinação do Poder Judiciário, a quem compete exercer a função correicional.

A pesquisa de campo evidenciou que parcela significativa das terras dos municípios onde a expansão dos plantios de dendê ocorreu mais acentuadamente foram incorporadas pelas grandes corporações do mercado de óleo de palma por diversas maneiras. Os meios mais comuns que se verificaram foram a compra de terras, o arrendamento fundiário de antigas fazendas de gado, o arrendamento de lotes reconcentrados irregularmente dentro de projetos de assentamento, a posse por simples ocupação em terras públicas federais e estaduais e a transferência das terras da reforma agrária, por meio do sistema de "integração".

Desta forma, o que se verifica é que a grilagem de terras é um mecanismo de apropriação que resiste e se renova ao longo do tempo, e assim contribui para moldar a 
Monocultivos de dendezeiros, capital transnacional e concentração

de terras na Amazônia Paraense
Elielson Pereira da Silva

Sônia Barbosa Magalhães

André Luís Assunção de Farias

estrutura fundiária atual, que é produto de tensões, conflitos e distintas racionalidades econômicas incrustadas no espaço regional.

\section{A invisibilidade legal da atual concentração de terras}

Em conformidade com o ordenamento jurídico brasileiro, a compra de terras normalmente se basearia em registros imobiliários emitidos pelos cartórios da região, e deveriam atender ao disposto no Decreto $n^{\circ} .4 .449 / 002$, que fixou a obrigatoriedade das áreas acima de 500 (quinhentos) hectares serem certificadas pelo órgão fundiário nacional, em caso de transação que implique em compra, remembramento e/ou desmembramento do imóvel. Ademais, qualquer aquisição de imóvel rural por estrangeiro deveria ser submetida à análise e deliberação do órgão fundiário federal, com a consequente publicação do ato no Diário Oficial da União.

De acordo com o previsto nas sucessivas Cartas Magnas a partir de 1934, a concessão e alienação de terras públicas acima do limite constitucional estabelecido está sujeita a prévia autorização do Congresso Nacional, sendo que o deferimento ocorrerá por meio de ato administrativo expedido pelo Senado Federal.

A tabela 4 mostra os atos expedidos para aqueles imóveis rurais localizados em território paraense que estão enquadrados na situação jurídica mencionada anteriormente, isto é, que ultrapassam o limite constitucional estabelecido desde a Constituição de 1934 e que vem se mantendo com pequenas alterações ao longo do tempo.

A sistematização das informações identifica que no intervalo temporal de 1934 a 2015 (81 anos), foram expedidas apenas 9 (nove) autorizações do Senado Federal para áreas acima do limite constitucional. Destas, 5 (cinco) se referem a imóveis rurais situados nos municípios da microrregião de Tomé-Açu, inclusive uma delas para a companhia agroindustrial Denpasa, que tinha um projeto de produção de dendê no município de Acará no início da década de 80. A intitulada Companhia Agrícola do Acará (Coacará), controlada pela Denpasa, foi vendida em 2000 para o grupo Agropalma, passando a se chamar Companhia Palmares da Amazônia (MÜLLER, 2006, p. 13). 
Monocultivos de dendezeiros, capital transnacional e concentração

Elielson Pereira da Silva de terras na Amazônia Paraense

Sônia Barbosa Magalhães André Luís Assunção de Farias

Tabela 4 - Atos Administrativos expedidos pelo Congresso Nacional para concessão e alienação de terras acima do limite constitucional no Estado do Pará

\begin{tabular}{|c|c|c|c|c|c|c|}
\hline $\begin{array}{l}\mathrm{N}^{0} \text { de } \\
\text { ordem }\end{array}$ & Nome do imóvel & $\begin{array}{c}\text { Tamanho } \\
\text { da área } \\
\text { (ha) }\end{array}$ & Nome do proprietário & Município & $N^{o}$ do ato & Data \\
\hline 1 & 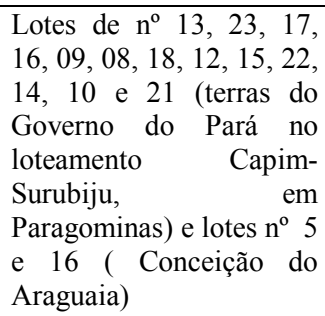 & indefinido & $\begin{array}{l}\text { Agropecuária do Rio } \\
\text { Capra }\end{array}$ & $\begin{array}{l}\text { Paragominas } \\
\text { e Conceição } \\
\text { do Araguaia }\end{array}$ & $\begin{array}{l}\text { Resolução } \\
\text { Senado no } \\
33\end{array}$ & $\begin{array}{l}02 / 10 / 19 \\
74\end{array}$ \\
\hline 2 & $\begin{array}{l}\text { Projeto de colonização } \\
\text { privada, situado na Gleba } \\
\text { Carapanã }\end{array}$ & $400.000,00$ & $\begin{array}{l}\text { Construtora Andrade } \\
\text { Gutierrez }\end{array}$ & Tucumã & $\begin{array}{l}\text { Resolução } \\
\text { Senado n } \\
89\end{array}$ & $\begin{array}{l}13 / 11 / 19 \\
79\end{array}$ \\
\hline & & $\begin{array}{r}2.976 \\
2.214,00 \\
2.998,00 \\
2.976,00\end{array}$ & $\begin{array}{l}\text { Antônio Miranda de } \\
\text { Oliveira } \\
\text { Francisco } \\
\text { Cruz Miranda } \\
\text { Rubens } \quad \text { Francisco } \\
\text { Miranda da Silva } \\
\text { José Miranda Cruz } \\
\text { Vicente Miranda Cruz }\end{array}$ & & & \\
\hline 3 & $\begin{array}{l}\text { Áreas desmembradas da } \\
\text { Fazenda Porto Alto }\end{array}$ & $2.996,00$ & $\begin{array}{l}\text { Arthur Rodrigues da } \\
\text { Silva }\end{array}$ & Acará & $\begin{array}{l}\text { Resolução } \\
\text { Senado } \mathrm{n}^{\circ}\end{array}$ & $\begin{array}{c}02 / 12 / 19 \\
80\end{array}$ \\
\hline & & $3.000,00$ & $\begin{array}{l}\text { Francisco Miranda de } \\
\text { Oliveira }\end{array}$ & & & \\
\hline & & $3.000,00$ & Osvaldo Miranda Cruz & & & \\
\hline & & $2.915,00$ & $\begin{array}{l}\text { José dos Reis Lopes da } \\
\text { Rocha }\end{array}$ & & & \\
\hline & & $3.000,00$ & Joaquim Miranda Cruz & & & \\
\hline & & $2.986,00$ & $\begin{array}{l}\text { Pedro Miranda de } \\
\text { Oliveira }\end{array}$ & & & \\
\hline 4 & Sem denominação & $30.000,00$ & $\begin{array}{l}\text { Maisa Moju } \\
\text { Agroindustrial SA }\end{array}$ & Moju & $\begin{array}{l}\text { Resolução } \\
\text { Senado } n^{\circ} \\
321\end{array}$ & $\begin{array}{c}23 / 08 / 19 \\
83\end{array}$ \\
\hline 5 & Fazenda Denpasa & $22.760,00$ & $\begin{array}{l}\text { Dendê do Pará SA - } \\
\text { DENPASA }\end{array}$ & Acará & $\begin{array}{l}\text { Resolução } \\
\text { Senado } \mathrm{n}^{\circ} \\
67\end{array}$ & $\begin{array}{c}21 / 11 / 19 \\
84\end{array}$ \\
\hline 6 & $\begin{array}{l}\text { Parte da Gleba Belo } \\
\text { Monte-A }\end{array}$ & $4.618,00$ & $\begin{array}{l}\text { Espólio de Iurdes } \\
\text { Braga Torres }\end{array}$ & $\begin{array}{l}\text { Senador José } \\
\text { Porfírio }\end{array}$ & $\begin{array}{l}\text { Resolução } \\
\text { Senado no } \\
117\end{array}$ & $\begin{array}{c}05 / 12 / 19 \\
84\end{array}$ \\
\hline 7 & $\begin{array}{l}\text { Gleba de terras adjacente } \\
\text { à Província Mineral de } \\
\text { Carajás }\end{array}$ & $411.948,87$ & $\begin{array}{l}\text { Companhia Vale do } \\
\text { Rio Doce }\end{array}$ & Marabá & $\begin{array}{l}\text { Resolução } \\
\text { Senado } n^{\circ} \\
331\end{array}$ & $\begin{array}{c}05 / 12 / 19 \\
86\end{array}$ \\
\hline 8 & Fazenda Santa Marta & $12.000,00$ & $\begin{array}{l}\text { Santa Marta } \\
\text { Agroindústria Ltda }\end{array}$ & Moju & $\begin{array}{l}\text { Resolução } \\
\text { Senado } \mathrm{n}^{\circ} \\
83\end{array}$ & $\begin{array}{c}30 / 06 / 19 \\
87\end{array}$ \\
\hline 9 & Fazenda Socôco & $16.000,00$ & $\begin{array}{l}\text { Socôco } \\
\text { Agroindústrias } \\
\text { Amazônia Ltda }\end{array}$ & Moju & $\begin{array}{l}\text { Decreto } \\
\text { Legislativ } \\
\mathrm{o} \mathrm{n}^{\circ} 805\end{array}$ & $\begin{array}{c}10 / 11 / 20 \\
03\end{array}$ \\
\hline
\end{tabular}

Fonte: Senado Federal, 2015.

O elemento central trazido por esse resultado é que nenhuma das atuais companhias produtoras de dendê na microrregião de Tomé-Açu, seja as de capital 
nacional ou aquelas de capital transnacional possuem autorização do Congresso Nacional para possuírem terras acima do limite previsto na Constituição Federal.

É uma situação que remete à discussão sobre a efetiva soberania do país em gerir adequadamente seu território e desnuda as agroestratégias que o grande capital põe em marcha para perpetuar ilimitadamente seus mecanismos de acumulação na Amazônia Paraense, os quais tendem a promover o cercamento de territórios tradicionalmente ocupados e o impulsionamento de conflitos sociais.

Neste contexto de apropriação das terras fica evidenciado o green grabbing enquanto mecanismo de conversão de áreas destinadas a outros usos em monocultivos de produção de óleo de palma, mediante uma narrativa que busca legitimar simbolicamente o dendê como um novo ciclo econômico impulsionador do desenvolvimento sustentável na região.

Por outro lado, quando se verifica a regularidade das transações imobiliárias de áreas privadas acima de 500 (quinhentos) hectares que foram incorporadas ao patrimônio fundiário das grandes empresas produtoras de óleo de palma, com base nos dados do Sistema de Gestão Fundiária (SIGEF), gerenciado pelo INCRA a situação é igualmente caótica.

Observe-se que a Lei $n^{0}$ 10.267/2001, regulamentada pelo Decreto $\mathrm{n}^{\mathrm{o}}$ 4.449/2002 e suas alterações, estabeleceu novos parâmetros para a organização dos mercados fundiários no país, com a instituição da obrigatoriedade de certificação de imóveis rurais de áreas superiores a 500 hectares quando forem transacionadas no mercado. A certificação consiste na aferição do regular destacamento da propriedade do patrimônio público para o particular e da não existência de sobreposições com outras áreas, o que se comprova por meio da apresentação da cadeia dominial e do georreferenciamento, respectivamente.

Com efeito, qualquer operação imobiliária de áreas cima de quinhentos hectares que implique em compra, venda, desmembramento e/ou remembramento atrairá a incidência da presente lei. O órgão fundiário responsável por essa ação pública é o INCRA, que por pressão do agronegócio, desenvolveu ferramentas e parcerias institucionais nos últimos anos para atendimento da demanda represada. Uma das iniciativas foi a criação do Sistema de Gestão Fundiária. 
A consulta ao SIGEF em junho de 2015 revelou que do total de imóveis rurais adquiridos pelas grandes companhias produtoras de óleo de palma apenas um encontrase certificado pelo INCRA, em observância aos preceitos legais anteriormente evocados. Trata-se de uma pequena propriedade intitulada Fazenda Belém I, com área de 79,5 hectares, em nome da empresa Belém Bioenergia, no município de Tailândia.

Depreende-se que o processo intenso de aquisição de terras empreendido pelas empresas Agropalma, Biopalma, Petrobrás Biocombustível, Galp Energia, Guanfeng Group e Marborges, que resultou na apropriação de 379.306,17 (trezentos e setenta e nove mil, trezentos e seis hectares e dezessete ares), equivalentes a $16 \%$ do território dos municípios que compõem a microrregião de Tomé-Açu, vem ocorrendo em absoluto desacordo com a legislação que rege o mercado formal de terras. Acevedo Marín e Backhouse (2014) e Nahum e Santos (2013) retratam os vários mecanismos utilizados pelas empresas para concentrar extensas faixas de terras na região, principalmente a compra, o arrendamento e a "integração" da agricultura familiar, em que se verifica a atuação de políticos locais que se metamorfosearam em corretores fundiários, abrindo caminho para a implantação dos grandes projetos do agronegócio do dendê.

Associado a fatores correlativos como o aquecimento vigoroso do mercado de terras evidenciado na análise das planilhas de preços referenciais de terras dos últimos 13 anos, a inexistência de autorizações legislativas para as áreas acima do limite constitucional e a potencialidade de conflito com comunidades tradicionais, este achado agrava ainda mais o quadro fundiário regional.

\section{Considerações finais}

Como construção social e política, o território é um ambiente em disputa, moldado por relações assimétricas de poder, onde múltiplos sujeitos buscam hegemonizar seus interesses, a partir de uma determinada concepção de desenvolvimento, territorializando suas ações e implicando na emergência de conflitos sociais e ambientais.

O Programa de Produção e Uso do Biodiesel e o Programa de Produção Sustentável de Óleo de Palma lançados pelo governo federal em 2004 e 2010, 
associados a iniciativas do Governo do Pará a partir da década de 90, numa perspectiva ufanista, elegeram o agronegócio do dendê como o grande projeto econômico a ser impulsionado nesta porção do território amazônico. Para isso, grandes companhias agroindustriais de capital transnacional foram atraídas para alocar investimentos estratégicos na produção de óleo de palma em larga escala na microrregião de ToméAçu, considerada a região mais apropriada sob a visão agronômica para a expansão desta nova commodity agrícola, e contraditoriamente, uma das mais frágeis do ponto de vista da regularidade fundiária.

A chegada do grande capital, acompanhada de novas práticas e formações discursivas com apelo socioambiental nos moldes do green grabbing, engendrou a apropriação de um grande estoque de terras, sob diversas formas. Aquisição de grandes fazendas, ocupação irregular de terras públicas, arrendamento e "integração" com agricultores familiares foram os meios utilizados para engendrar uma nova configuração na estrutura fundiária regional.

A expansão dos monocultivos de dendezeiros, num amplo processo de concentração "dinamizou" o mercado fundiário, resultando na consequente sobrevalorização e estrangeirização das terras, que passaram a ser incorporadas aos ativos de grandes companhias transnacionais. O ritmo de produção e uso da terra passou a ser ditado pela dinâmica do mercado internacional de commodities.

O intenso fluxo de mercantilização das terras tem afetado as relações sociais na região, uma vez que é possível identificar instrumentos de acumulação por despossessão que promovem a expropriação e o cercamento de territórios tradicionalmente ocupados, modificam a estrutura de trabalho familiar, afetam a soberania alimentar e subordinam o destino das famílias a comandos exógenos.

Observa-se então que este processo de apropriação dos recursos naturais no território vem ocorrendo em desacordo com a legislação vigente que versa sobre regularização fundiária, especialmente no que dispõe a Constituição Federal. Nenhuma das companhias transnacionais detém autorização expressa do Congresso Nacional para possuir áreas acima do limite constitucional, embora todas elas exerçam o controle efetivo sobre grandes extensões de terras com monocultivos de dendedeiros na Amazônia Paraense. Não obstante, a aquisição de terras pelas empresas, equivalente a $16 \%$ do território que compreende a microrregião de Tomé-Açu, ocorreu na contramão 
Monocultivos de dendezeiros, capital transnacional e concentração

de terras na Amazônia Paraense
Elielson Pereira da Silva

Sônia Barbosa Magalhães

André Luís Assunção de Farias

do previsto no ordenamento jurídico que rege as transações imobiliárias acima de 500 hectares, evidenciando com isso a ilegitimidade com que essas terras foram incorporadas ao patrimônio das companhias nacionais e transnacionais do agronegócio do dendê.

A conjunção de fatores ora evidenciada tende a agravar a realidade social e agrária regional, historicamente marcada por conflitos sociais e ambientais, uma vez que, se por um lado o grande projeto econômico de longo prazo tem buscado meios de legitimar as terras adquiridas precariamente, as comunidades tradicionais por sua vez organizam formas de resistência que resguardem a proteção de seus territórios e de seu modo de vida.

Resta saber se o Estado continuará atuando como indutor do conflito, por meio de políticas governamentais discursivamente alinhadas a narrativas endógenas de desenvolvimento, mas que na prática perpetuam formas de poder e dominação hegemônicas, ou se haverá permeabilidade institucional para ampliar a participação da sociedade civil na construção de possibilidades que valorizem a diversidade social e cultural das localidades.

\section{Notas}

\footnotetext{
${ }^{1}$ Em outro momento na obra de Marx ele questiona esse próprio conceito de liberdade do proletariado, no momento em que percebe a apropriação da mão-de-obra é condicionada pelo mercado de trabalho.

${ }^{2}$ De acordo com Backhouse (2013, p. 4), o green grabbing consiste em múltiplos processos de tomada, apropriação ou privatização de terras impulsionados por medidas de proteção ao clima e ao meio ambiente.

${ }^{3}$ Para um aprofundamento melhor do processo histórico da questão agrária brasileira ver Guimarães (1968).
}

\section{Referências}

ACEVEDO MARÍN, Rosa; BACKHOUSE, Maria (Orgs.). Projeto Nova Cartografia Social da Amazônia, Belém, Boletim Informativo, n. 9, ago. 2014.

ALMEIDA, Alfredo W.B. de. A reconfiguração das agroestratégias: novo capítulo da guerra ecológica. In: SAUER, S; ALMEIDA, W (org).Terras e territórios na Amazônia: demandas, desafios e perpectivas. Brasília: Editora Universidade de Brasília, 2011. p. 27-44 
ALMEIDA, Alfredo W.B. de; ACEVEDO MARÍN, Rosa A. Campanhas de desterritorialização na Amazônia: o agronegócio e a reestruturação do mercado de terras. In: BOLLE, W; CASTRO, E.C; VEJMELKA, M. Amazônia: região universal e teatro do mundo. São Paulo: Globo, 2010. p. 141-159

ALTVATER, Elmar. Existe um marxismo ecológico. In: BORON, A.; AMADEO, J.; GONZALEZ, S. (Orgs). A teoria marxista hoje: Problemas e perspectivas. CLACSO, $2007 . \quad$ Disponível em: $<$ http://bibliotecavirtual.clacso.org.ar/ar/libros/campus/marxispt/cap.15.doc $>$. Acesso em: 01 mar. 2015. p. 360-385

BANCO DA AMAZÔNIA. A experiência do Banco da Amazônia com projetos integrados de dendê familiar. Revista Contexto Amazônico, ano 5, n. 22, jun. 2012.

BACKHOUSE, Maria. A desapropriação sustentável da Amazônia. O caso de investimentos em dendê no Pará: Fair Fuels? Working Paper 6, Berlin: 2013. Disponível em: $\quad<$ http://www.fair-fuels.de/data/user/Download/ Veröffentlichungen/FairFuels Working_Paper_6_Portuguese.pdf $>$ Acesso em: $01 \mathrm{abr}$. 2015.

BRASIL. Programa de Produção Sustentável da Palma de Óleo no Brasil. Brasília, DF, 2010. 9 p.

BRASIL. Senado Federal. Portal de Legislação. 2015. Disponível em: $<$ http://legis.senado.leg.br/sicon/\#/basica> Acesso em: 10 mar. 2015.

BENATTI, José H. Regularização fundiária e direitos de propriedade na Amazônia brasileira. In: CGEE. Projeto Nacional para o Desenvolvimento da Amazônia: Projeto Amazônia: questão fundiária. Brasília, DF: CGEE, 2008. p. 01-42.

BOARI, Alessandra J. O desafio das pesquisas com a etiologia do Amarelecimento Fatal (AF) da cultura da palma de óleo. In: RAMALHO FILHO, A. et al. Zoneamento Agroecológico, produção e manejo da cultura de palma de óleo na Amazônia. Rio de Janeiro: Embrapa Solos, 2010. p. 153-165

CONSELHO NACIONAL DE JUSTIÇA. Decisão da Corregedoria de Justiça sobre o Pedido de Providências $\mathbf{n}^{0}$ 0001943.67.2009.2.00.0000. Brasília, 16 de agosto de 2010.

DELGADO, Guilherme. Questão agrária hoje. Revista da Associação Brasileira de Reforma Agrária, São Paulo, 01, n. 02, out. 2014. 27-40.

FAIRHEAD, James; LEACH, Melissa; SCOONES, Ian. Green Grabbing: a new appropriation of nature? The Journal of Peasant Studies, 39:2, 237-261, DOI: $10.1080 / 03066150.2012 .671770 . \quad$ To link to this article: http://dx.doi.org/10.1080/03066150.2012.671770 
Monocultivos de dendezeiros, capital transnacional e concentração de terras na Amazônia Paraense
Elielson Pereira da Silva

Sônia Barbosa Magalhães André Luís Assunção de Farias

GUIMARÃES, Alberto P. Quatro séculos de latifúndio. Rio de Janeiro: Paz e Terra, 1968.

HARVEY, David. Os limites do capital. São Paulo: Boitempo, 2013.

HÉBETTE, Jean. Cruzando a fronteira: 30 anos de estudo do campesinato na Amazônia. Belém: EDUFPA, 2004.

HOFFMANN, Rodolfo; NEY, Marlon G. Estrutura fundiária e propriedade agrícola no Brasil, grandes regiões e unidades da federação. Brasília, DF: NEAD/MDA, 2010 .

LOUREIRO, Violeta; PINTO, Jax. A questão fundiária na Amazônia. Estudos Avançados, v. 19, n. 54, 2005. Disponível em: $<$ http://www.scielo.br/pdf/ea/v19n54/04.pdf >. Acesso em: 27 set. 2014.

MARX, Karl. O Capital: crítica da Economia Política. Tradução de Regis Barbosa e Fábio R. Koche. São Paulo: Nova Cultural, v. I, 1988.

MONTEIRO, Marcílio de A. Os impactos dos biocombustíveis nas trajetórias dos camponeses da Amazônia. Atas. I Encontro Lusófano em Economia, Sociologia, Ambiente e Desenvolvimento Rural. s.1. 2013. p. 3317-3336.

MÜller, Antonio A. A Embrapa Amazônia Oriental e o agronegócio do dendê no Pará. Belém, Pará: Embrapa Amazônia Oriental, 2006. 67 p.

NAHUM, João dos S.; MALCHER, Antônio T.C. Dinâmicas territoriais do espaço agrário na Amazônia: a dendeicultura na microrregião de Tomé-Açu (PA). Confins, $n$. 16, 2012. Disponível em: <http://confins.revues.org/7947; DOI:10.4000/confins.7947>. Acesso em: 10 fev. 2014.

NAHUM, João dos S.; SANTOS, Cleison B. dos. Impactos socioambientais da dendeicultura em comunidades tradicionais na Amazônia paraense. ACTA Geográfica, Boa Vista, Ed. Especial Geografia Agrária, 2013. p. 63-80.

Dendeicultura e descampesinização na Amazônia Paraense. Campo-Território, v. 9, n. 17, p. 469-485, 2014.

OLIVEIRA, Ariovaldo U. de. Modo de Produção Capitalista, Agricultura e Reforma Agrária. São Paulo: FFLCH, 2007. 1-184 p.

POLANYI, Karl. A grande transformação. Rio de Janeiro: Compus, 2000.

$\overline{\text { Contraponto, } 2012 .}$

A subsistência do homem e ensaios correlatos. Rio de Janeiro: 
Monocultivos de dendezeiros, capital transnacional e concentração de terras na Amazônia Paraense
Elielson Pereira da Silva Sônia Barbosa Magalhães André Luís Assunção de Farias

RAMALHO FILHO, Antônio et al. Zoneamento Agroecológico, produção e manejo da cultura de palma de óleo na Amazônia. Rio de Janeiro: Embrapa Solos, 2010. 216 p.

SAMPAIO, Irã C. A agricultura familiar e a agroindústria do dendê no município de Tomé-Açu (PA): efeitos da agricultura por contrato na produção e no trabalho familiar. 2014. 198 f. Dissertação (Mestrado) - Programa de Pós-Graduação em Sociologia e Antropologia, Universidade Federal do Pará, Belém.

SOUSA, Claudiane F.M. de. Será mesmo o diabo? Expansão da dendeicultura e o campesinato na Amazônia Paraense. 2015. 188 p. Dissertação (Mestrado) - Programa de Pós-Graduação em Sociologia e Antropologia, Universidade Federal do Pará, Belém.

TRECCANI, Girolamo D. Violência e grilagem: instrumentos de aquisição da propriedade da terra no Pará. 2006. 600 f. Tese (Doutorado em Ciências Jurídicas) Instituto de Ciências Jurídicas/Universidade Federal do Pará, Belém-PA.

PARÁ. Tribunal de Justiça do Pará. Corregedoria de Justiça das Comarcas do Interior. Provimento $\mathbf{n}^{\mathbf{0}}$ 02, de 23 de agosto de 2010.

Provimento no 13, de 21 de junho de 2013.

SACRAMENTO, Elias D. As almas da terra: a violência no campo paraense. 2007. 186 f. Dissertação (mestrado) - Universidade Federal do Pará, Belém-PA.

VIEIRA, A. C. C. A "integração" camponesa ao monocultivo de dendê: subordinação e transformação do campesinato amazônico. 2015. 139 f. Dissertação (mestrado) - Universidade Federal do Pará, Belém-PA.

VIEIRA, Ana C.; MAGALHÃES, Sônia M. B. Transformações no espaço rural amazônico: o plantio de dendê em comunidades camponesas do Baixo Tocantins, município de Moju/PA. Belém, 2012.

VINHAS, Moisés. Problemas agrário-camponeses do Brasil. In: STÉDILE, João P. (Org.). A questão agrária no Brasil: o debate tradicional: 1500-1960. São Paulo: Expressão Popular, 2005. p. 127-168. 